\title{
Aspek Sosial dalam Implementasi Sistem Informasi di Perpustakaan
}

\author{
Studi Kasus Tentang Aspek Sosial Kognitif dalam Implementasi Sistem \\ Infomasi pada Proses Migrasi dari Unicorn Sirsidynix ke Symphony \\ Sirsidynix pada Tahun 2013 di Unit Pelaksana Teknis Perpustakaan \\ Universitas Jember
}

\author{
Ida Widiastuti \\ Perpustakaan Universitas Jember
}

\begin{abstract}
Abstrak - Penelitian ini mengunakan teori konstruksi sosial teknologi (Social Construction Of Technology Theory) dan teori Technological Frame, dimana metodelogi yang digunakan adalah metode kualitatif, dengan tujuan untuk mendapatkan gambaran yang lengkap mengenai aspek sosial kognitif dalam implementasi sistem informasi di perpustakaan Universitas Jember.Untuk mendapatkan tujuan ini, digunakan wawancara dan observasi. Wawancara dilakukan dengan mendasarkan pada teori technological frame dengan konsepnya yakni nature of technology; technology strategy; technology in use. Berdasar teori ini juga, aktor yang terlibat dalam penelitian adalah kelompok profesional yang dikategorikan menjadi kelompok manajemen; Teknisi ; dan kelompok user.Hasil penelitian menunjukan disamping terdapat persamaan, juga terdapat banyak perbedaan dalam aspek kognitif diantara kelompok sosial yang terlibat dalam implementasi sistem informasi. Perbedaan aspek kognitif ini berarti bahwa aktor cenderung berada pada posisi inkongruen. Mengacu pada konsep tecnological frame, ketika inkongruen dalam technological frame eksis, organisasi akan mengalami kesulitan dan konflik seputar membangun, mengimplementasikan dan menggunakan teknologi tersebut.
\end{abstract}

Abstract - This research used the Social Construction of Technology (SCOT Theory) and the Technological Frame Theory with Qualitative Methodology, with the purpose to obtain a complete description on social cognitive aspects in the implementation of information system technology at the library of Jember University. To attain these objectives, data collection is obtain through interviews and observation. The interviews were conducted based on the Technological Frames Theory and its concept of nature of technology; technology strategy; and technology in use. According to the framework of Orlikowski and Gash (1994), the actors in this research are professional groups which are categorized as managers; technologists; and users. The results showed that in the implementation of information technology at Jember University Library, beside similarity, are also found a lot of dissimilarities on shared cognitive among social groups. Dissimilarities mean, the actors are in the incongruent position. According to Technological Frames theory, if incongruent exists, organizations will have difficulties and conflicts in developing, implementing and using technologies.

Keywords: Information Systems, Library Information System Technology, Social Aspect, Information System Technology Implementation

\section{PENDAHULUAN}

Sistem informasi di perpustakaan merupakan bagian yang tidak terpisahkan dari manajemen perpustakaan. Dalam manajemen Perpustakaan, sistemin formasi digunakan untuk mengelola sumber daya informasi yang ada di Perpustakaan seperti pengadaan bahan pustaka, pengolahan bahan pustaka, layanan jasa perpustakaan, administrasi perpustakaan, serta laporan-laporan yang berguna bagi pihak manajemen.

Migrasi sistem informasi di Perpustakaan dalam konteks manajemen perpustakaan diantarnya ditujukan untuk mengoptimalkan pengelolaan informasi dan sumber-sumber informasi untuk tujuan dimanfaatkan secara maksimal oleh masyarakat yang membutuhkannya.

UPT PerpustakaanUniversitasJembertelah menggunakan teknologi sistem informasi di Perpustakaan sejak tahun 1998 dengan menggunkan aplikasi Dynix. Pada tahun 2007 dilakukan proses migrasi Sistem Informasi dari Program Dynix menjadi program UNICORNSirsiDynix. Program Dynix yang sebelumnya hanya dapat diakses secara lokal dalam gedung UPT Perpustakaan, sejak saat itu dapat diakses secara global melalui jaringan internet. Namun 
demikian masih ada keterbatasan user license pada modul untuk pengolahan koleksi dan modul sirkulasi. Untuk selanjutnya, berdasar pada beberapa pertimbangan, kembali dilakukan proses migrasi dari Unicorn-SirsiDynix ke program SirsiDynix Symphony pada tahun 2013.

Sistem informasi Sirsidynix Symphony ini memiliki banyak kelebihan dibanding UnicornSirsidynix, Meskipun di Indonesia baru digunakan oleh Universitas Jember, namun tercatat sekitar 23.000 perpustakaan di 70 negara di seluruh dunia menggunakan apliksi yang dikembangkan Sirsidynix ini. Bila pada sistem sebelumnya user license hanya 24 , maka pada sistem yang baru tersedia user license tidakterbatasdan sudah menyertakanaplikasi-aplikasi lain, antara lain: Aplikasi sistem symphony yang digunakan untuk pengolahan, pelayanan dan administrasi; Aplikasi sistem Portofolio yang merupakan Digital Library system yang digunakan untuk pengelolaan digital Resource; Aplikasi sistem Enterprise yang digunakan untuk Online Public Access Catalogue (OPAC); Aplikasi sistem Director Station yang digunakan untuk laporan-laporan; dan Aplikasi BookMyne yang bisa digunakan untuk layanan mobile menggunakan Android

Berkaitan dengan itu berdasarkan pengamatan peneliti, pada masa transisi pasca migrasi sistem informasi seringkali dijumpai permasalahan teknis yang akhirnya mengurangi kualitas layanan, seperti masalah pada buku yang akan dipinjam, sistem yang lambat, data migrasi yang belum sempurna, dsb yang pada akhirnya berpengaruh pada elemen lainnya seperti layanan yang tidak sesuai dengan yang dijanjikan, banyaknya keluhan dari pemustaka, komunikasi internal yang tidak lancar dan perubahan lainnya.

Fakta yang terjadi dilapangan ini menarik untuk diamati lebih mendalam karena idealnya pengembangan sistem informasi melalui proses migrasi ini menghasilkan proses layanan yang lebih baik, proses pengolahan yang lancar, meningkatkan kualitas layanan dan pada akhirnya mampu memuaskan pemustaka. Karena itu peneliti melihat pentingnya memahami aspek lain selain aspek teknis dalam implementasi sistem informasi sebagaimana disampaikan oleh Putu Laxman Pandit(2011) bahwa Perpustakaan dan kepustakawanan (librarianships) merupakan fenomenasosio-teknis yang sudah ada sejak peradaban manusia mengenal tulisan; sebab itu fenomena ini amat kompleks (rumit).

Aspek lain di luar teknis dalam penelitian ini adalah aspek-aspek sosial kognitif dalam implementasi sistem informasi di perpustakaan. Dengan mendasarkan pada teori Technological Frame yang menggunakan pendekatan sosial kognitif, penelitian ini ditujukan untuk: Memahami bagaimana sifat dasar teknologi (nature of technology) sistem infromasi yang diimplementasikan; Memahami bagaimanastrategi teknologi (technology strategy) yang dilakukan dalam implementasi teknologi sistem informasi; dan Memahami bagaimana penggunaan teknologi (technology in use) dalam implementasi sistem informasi di Perpustaakaan Unversitas Jember. Dengan harapan penelitian ini bisa memperkaya referensi dan kajian tentang aspek sosial kognitif dalam implementasi teknologi sistem informasi di Perpustakaan serta pemanfaatannya.

\section{METODELOGI}

Penelitian ini menggunakan menggunakan metode kualitatif, dengan paradigma interpretif yang digunakan untuk mendapatkan gambaran yang mendalam mengenai aspek sosial kognitif dalam implementasi sistem informasi pada kasus proses migrasi sistem infromasi. Pendekatan kualitatif dalam penelitian implementasi sistem informasi ini adalah tepat, berdasar pada pendapat Orlikowski dan Baroudi (1991) bahwa penelitian interpretif yang menekankan makna subyektif dimana aktor manusia memberikan makna pada teknologi dalam konteks implementasi dan penggunaannya adalah sesuai untuk menyelidiki pelaksanaan sistem informasi (dalam Sahay \& Robey, 1996: 258).

Sesuai dengan pendekatan kualitatif, peneliti memanfaatkan berbagai sumber data yakni : wawancara terbuka, untuk menggali dan memahami asumsi, ekspektasi dan harapan aktor dalam penelitian ini; observasi; dan dokumentasi. Dengan demikian peneliti tidak bertumpu pada satu sumber data. Kemudian peneliti mereview semua data tersebut, memberikannya makna, dan mengolahnya ke dalam kategori-kategori atau tema-tema yang melintasi semua sumber data, sebagaimana disampaikan Creswell (2012: 261).

Dalam penelitian ini, peneliti menggunakan jenis studi kasus tunggal, karena memberi 
kemungkinan peneliti untuk melakukan eksplorasi secara mendalam tentang kejadian tertentu dari sebuah fenomena. (Cresswell dalam Daymon:167). Dengan demikian upaya untuk mentransfer gagasan pada wilayah yang lebih luas tidak menjadi kepentingan peneliti pada studi kasus ini, karena peneliti lebih tertarik untuk fokus pada ranah kasus itu sendiri dengan harapan sebagaimana disampaikan Daymon \& Immy Holloway (2008:174), untuk menghadirkan uraian yang padat (thick description) mengenai proses-proses yang kompleks dan pengaruhnya dalam konteks tertentu. Menurut Robert K. Yin, dengan menggunakan metode studi kasus, peneliti bisa mempertahankan sifat holistik dan bermakna dari proses-proses organisasi maupun manajemen, serta dalam perubahan lingkungan sosial. (Yin,2013:4).

\section{Teknik Penentuan Key Informan}

Dalam menentukan informan kunci dalam penelitian ini, peneliti menggunakan metode purposive sampling yaitu menentukan informan berdasarkan pertimbangan tertentu, sebagaimana disampaikan Daymon \& Immy Holloway (2008:174) bahwa teknik penarikan sampel studi kasus terjadi pada dua level yaitu pada kasus itu sendiri dan pada para partisipan.

Dalam Technological Frame, Orlikowski \& Gash (1992) membedakan aktor yang berperan dalam implementasi sistem informasi menjadi 3 grup sosial yakni grup managers, technologist, dan user. Sejalan dengan konsepnya, maka aktor dalam penelitian ini dikategorikan menjadi 3 kelompok yakni kelompok manajemen, kelompok Teknologi Informasi (selanjutnya disebut teknisi), dan kelompok user baik yang mengoperasikan sistem informasi (untuk selanjutnya disebut user operator), maupun user dari pemustaka (untuk selanjutnya dalam penelitian ini disebut user pemustaka).

\section{HASIL DAN PEMBAHASAN}

Untuk memahami bagaimana aspek sosial dalam implementasi sistem informasi di perpustakaan berdasar pada teori technological frame, hasil penelitian ini dikategorikan dalam domain yang ada dalam teori technological frame, yaitu sifat dasar teknologi (nature of technology), strategi teknologi (technology strategy), dan penggunaan teknologi (technology in use).

\section{Gambaran Kelompok Profesional di} Perpustakaan Mengenai Sifat Dasar Teknologi (Nature of Technology) dalam Implementasi sistem informasi.

Nature of Technology adalah bagaimana imej teknologi di mata aktor, termasuk pemahaman mereka tentang fungsi dan kemampuan teknologi tersebut (Orlikowski \& Gash, 1994: 183).

\section{Gambaran Kelompok Profesional di Perpustakaan Mengenai Imej Teknologi Sistem Informasi Symphony}

Kelompok manajemen memiliki imej yang sangat positif, tergambar dalam pernyataan mereka ketika ditanya bagaimana pandangannya pada Teknologi Sistem Informasi yang baru diimplementasikan. Mahfut Aslam ${ }^{1}$ mengatakan:

Kalau dari teknologinya menurut saya sudah perfect ya. Dalam artian selalu terus dikembangkan sesuai masukan dari user, apalagi perusahaan sirsidynix yang sudah bertaraf internasional yang sudah lama... Dimana jangkauannya sudah jauh ke depan.

Pendapat kelompok manajemen tersebut, didukung oleh teknisi ${ }^{2}$ yang dengan yakin mengatakan:

Kalau dari teknologi saya melihat teknologi kita paling maju mungkin di Jatim paling maju, kalau saya bilang sistem ini paling wah, paling bagus, saya dukung sistem ini nomor satu, menurut saya yah.

Sejalan dengan pendapat manajemen dan teknisi, sebagian besar informan dari kelompok user opertor memiliki imej yang cukup positif terhadap Teknologi Sistem Informasi Symphony yang sedang diimplementasikan di perpustakaan. Sebagaimana tergambar dalam pendapat mereka ketika ditanya pandangannya mengenai Symphony. Namun demikian, meskipun tidak meragukan sistem Symphony beberapa informan memiliki catatan penting untuk dipertimbangkan, seperti yang disampaikan Khusnun ${ }^{3}$ :

Lebih canggih lah. Kekurangaanya ketika ada troubel kita tergantung sama vendornya.

Begitupun dengan Teknisi ${ }^{4}$ berpendapat:

${ }^{1}$ Sekretaris UPT Perpustakaan, dalam wawancara tanggal 20 Februari 2014

${ }^{2}$ Taufik Hermansyah, wawancara 21 Januari 2014

${ }^{3}$ staf sirkullasi, wawancara 11 Februari 2014

${ }^{4}$ Taufik, wawancara 21 Januari 2014 
Menurut saya dalam sistem ini ada beberapa fitur yang belum terpakai. Mungkin di tempat lain terpakai...

Sementara kabid Pengembangan dan kerja sama ${ }^{5}$ berpendapat:

Dari sisi pencitraan kita boleh berbangga menggunakan sistem Informasi yang berstandar Internasional. Namun sayang ketika alat ini tidak dimanfaatkan secara maksimal oleh petugas....

Pendapat yang sangat kontras muncul dari kelompok user pemustaka, semua informan menyatakan tidak tahu ketika ditanya apakah mereka mengetahui adanya perubahan sistem informasi pada tahun 2012.

Dari hasil penelitian, Informan yang dikelompokan dalam user operator dan teknisi cenderung memiliki kesamaan imej yang positif terhadap teknologi dengan kelompok manajemen, tapi berbeda dengan pandangan manajemen, mereka mencatat teknologi ini belum dimaksimalkan.

Dalam konsep technological frame individu dalam satu kelompok cenderung berbagi pengetahuan berdasarkan pengalaman selama berinteraksi dengan teknologi. Hal ini sesuai dengan pendapat Burkhardt (1994) dan Fulk, (1993) dalam Sahay \& Robey (1996, 260):

Technological frames are likely to be shared within a relevant social group because members share common relationships and experiences with a particular technical application.

Pada kondisi tersebut, kelompok manajemen, teknisi, dan user operator berada pada posisi kongruen dalam pandangan mereka mengenai imej sistem informasi symphony. Namun setelah berinteraksi dengan sistem informasi ini, diantara kelompok manajemen dengan kelompok aktor lainnya (teknisi dan dan user) berada pada posisi inkongruen dalam hal imej mereka terhadap sistem informasi symphony. Mengacu pada konsep Orlikowski \& Gash (1994:180) inkongruen dalam hal ini terjadi karena adanya perbedaan dalam asumsi, ekspektasi dan pengetahuan diantara kelompok user pemustaka dan kelompok akor lainnya.

\section{Gambaran Kelompok Profesional di Perpustakaan Mengenai Kemampuan Teknologi Sistem Informasi Sirsidynix}

Pandangan Kelompok Profesional di Perpustakaanmengenai kemampuan teknologi sistem informasi ini, tidak lepas dari pengalaman interaksi mereka dengan sistem informasi saat ini dan sistem informasi sebelumnya dari vendor yang sama. Setelah lebih kurang satu tahun menggunakan Sistem Infromasi Symphony Sirsidynix. Sebagian besar informan kelompok user operator tidak meragukan kemampuan Teknologi Sistem Informasi yang sedang diimplementasikan saat ini, namun di sisi lain mereka menilai tidak ada perbedaan yang signifikan dengan sistem informasi sebelumnya. Berdasarkan pengamatan dan wawancara, hal ini disebabkan antara lain: 1) Karena selama ini semua user operator berinteraksi dengan sistem ini sebatas pada apa yang berhubungan dengan pekerjaan mereka (rutinitas); 2) Kurangnya pengetahuan terhadap Sistem Informasi Symphony yang merupakan Integrated Library System yang memiliki 5 aplikasi berbeda di dalamnya; 3) Kurangnya motivasi untuk memahami sistem ini secara lebih jauh, karena dilapangan sebagian besar informan merasa pekerjaan rutinnya

Sementara itu, banyaknya masalah yang sering dijumpai di Sirkulasi, menjadi latar belakang pendapat yang lebih pesimis di bagian sirkulasi. Seperti disampaikan Kabid Sirkulasi ${ }^{6}$ :

Menurut saya dari sistem sekarang ini banyak kekurangannya. Kayanya lebih baik yang lama, kan nggak ada masalah.

Membandingkan dengan sistem Unicorn, hal senada diungkapkan staf sirkulasi ${ }^{7}$ :

Kalau dibanding dulu, masalahnya juga banyak sekarang, kadang masalah itu juga bukan kesalahan sistem karena musibah jaringannya atau dari hardwarenya dsb. Tapi kan orang bisa berpikiran..habis ganti sistem ini ko malah mbulet (Bahasa Jawa: ruwet)

Kondisi di bidang sirkulasi tersebut menggambarkan bagaimana anggota suatu kelompok sosial dari bagian yang sama dalam hal ini bagian sirkulasi, cenderung memilki asumsi, ekspektasi, dan pengetahuan yang sama.

\footnotetext{
${ }^{6}$ Sofi, wawancara 28 Februari 2014

${ }^{7}$ Khusnun, dalam wawancara 10 Februari 2014
} 
Termasuk dalam memaknai teknologi yang diimplementasikan di Perpustakaan.

Realitas tersebut sesuai dengan yang dikemukakan Orlikowski \&Gash (1994), dimana dalam beberapa literatur sosial kognitif dikemukakan kuatnya pengaruh dari grup atau kelompok dalam mempengaruhi sistem pengetahuan, makna, dan norma-norma untuk diarahkan pada anggota-anggota dan menciptakan perbedaan-perbedaan dalam minat serta orientasi diantara komunitas. Karena menurutnya orang cenderung berbagi asumsi, pengetahuan, dan ekpektasi dengan lainnya yang memiliki kedekatan hubungan dalam pekerjaan.

Dari hasil penelitian, dalam menilai kemampuan sistem informasi ini, sebagian besar kelompok user operator dan pemustaka, kelompok manajemen dan teknisi berada pada posisi inkongruen. Mengacu pada konsep technological frame Orlikowski \& Gash (1994:180) inkongruen dalam hal ini terjadi karena adanya perbedaan dalam asumsi, ekspektasi dan pengetahuan mengenai kemampuan sistem informasi symphony.

\section{Gambaran Kelompok Profesional di Perpustakaan Mengenai Fungsi Teknologi Sistem Informasi Symphony}

Manajemen memiliki pandangan mengenai fungsi Teknologi Sistem Informasi secara umum, menurutnya:

Sistem ini bisa mendukung rentstra(rencana strategis) Universitas. Yaitu Visi Misi Universitas untuk menjadi Universitas berskala internasional. Program ini/Sofware ini sudah berstandar internasional dipersiapkan untuk antisipasi jangkapanjang, sangat lengkap software ini sangat mendukung. ${ }^{8}$

Selain itu secara strategis dengan peningkatan Sistem Informasi ini manajemen mengharapkan adanya kemudahan akses, lalu efektifitas, dan keluasan akses.

Sementara manajemen mengharapkan sistem informasi ini bisa berfungsi maksimal secara strategis bagi organisai, sebagian besar informan mengarahkan fungsinya lebih pada tugas yang mereka lakukan, seperti yang disampaikan oleh hampir semua kelompok user operator:
Fungsinya untuk statistik, kita bisa melihat laporan. ${ }^{9}$

Fungsinya Yah mempermudah. Menghemat waktu, tenaga, biaya. Untuk perpustakaan yah bagus untuk statistik, untuk peminjaman.... ${ }^{10}$

Penerapannya ya terutama pengolahan dan pelayanan pemustaka. ${ }^{11}$

Fungsinya kan untuk mempermudah penelusuran, untuk temu kembali user ya... ${ }^{12}$

Fungsinya sangat membantu pekerjaanpekerjaan karyawan. Sehingga pekerjaannya lebih lancar... ${ }^{13}$

Dalam technological frame, kelompokkelompok aktor mungkin berbeda satu sama lainnya. Misalnya, pengembang dan pengguna sistem informasi biasanya membangun frame yang berbeda makna karena interaksi mereka dengan aplikasi tertentu berbeda dan mereka datang dari posisi sosial yang berbeda latar belakang pendidikan, lingkungan historis , dan kepentingan (Beath \& Orlikowski, 1994; Newman \& Robey , 1992

\section{Gambaran Kelompok Profesional di Perpustakaan Mengenai Strategi Teknologi dalam Implementasi SistemInformasi di Perpustakaan UNEJ}

Dalam konsep technological frame, strategi teknologi yang dimaksud adalah bagaiman pemahaman semua kelompok aktor tentang motivasi dibalik pengadaan, serta nilai-nilai yang diharapkan dari implementasi teknologi sistem informasi

\section{Gambaran Kelompok Profesional di Perpustakaan Mengenai Motivasi di Balik Pengadaan Software Symphony}

\footnotetext{
${ }^{9}$ Sukesi, Kabid. Pembinaan Koleksi, 7 Februari 2014

${ }^{10}$ Khusnun, Pustakawan Sirkulasi, 10 Februari 2014

${ }^{11}$ Maya, Pustakawan Bag. Pengadaan, 4 Februari 2014

12 Sofi, Kabid. Sirkulasi, 28 Februari 2014

${ }^{13}$ Iswahyudi, 17 Februari 2014
} 
Kelompok manajemen mengemukakan pertimbangan mengapa teknologi sistem informasi di pilih kembali di Perpustakaan Universitas Jember. Menurut Mahfut Aslam ${ }^{14}$ :

Pertimbangan pertama karena sebelumnya kita menggunakan software yang sama. Dari perusahaan yang sama. Jadi terus dilakukan peningkatan aplikasi yang digunakan, dari Dynix, ke Unicorn Sirsidynix, kemudian ke Symphony Sirsidynix. Kedua, karena pertimbangan renstra Universitas yaitu Visi Misi Universitas untuk menjadi Universitas bersekala Internasional. Ketiga, software produk Sirsidynix itu paling banyak digunakan di dunia.

Pertimbangan kenapa memilih menggunakan software ini dipahami hampir serupa oleh sebagian besar informan baik di kelompok user operator maupun teknisi. Meskipun mereka tidak tahu secara persis motivasi dibalik pengadaan dan pengembangan teknologi sistem informasi saat ini, sebagian besar memandang alasan utamanya adalah keberlanjutan sistem ini dari sistem sebelumnya. Seperti diungkapkan Teknisi ${ }^{15}$ :

Kalau menurut saya ada kesinambungan dengan sistem yang lalu. Dulu ketika datang Dynix, dulu manual kemudian komputerise jadi lebih mudah. Jadi sebetulnya kita beli sistem dynix. Harus lihat sejarah dulu

Kondisi tersebut menggambarkan bahwa asumsi dan ekspektasi sebagian besar kelompok aktor baik manajemen, teknisi, dan user operator berada pada posisi kongruen. Kongruen dalam hal ini semua kelompok aktor dalam implementasi sistem informasi symphony di perpustakaan memiliki kesamaan pandangan dalam memahami motivasi dibalik pengadaan sistem informasi symphony ini.

Kondisi seperti itu sesuai gagasan Orlikowski \& Gash (1994:180) yang mengungkapkan bahwa kongruen dalam technological frame bisa berimplikasi pada kesamaan ekspektasi sekitar peran teknologi, cara teknologi digunakan, atau tipe dan frekuensi dari pendukung dan pemeliharaan teknologi.

Berkaitan dengan strategi dan perencanaan, hasil penelitian menunjukan bahwa manajemen memang tidak membuat perencanaan yang jelas. Seperti diungkapkan Tri Lestari:

Sepertinya belum ada (perencanaan-pen). Sepertinya jalan begitu saja, sehingga proses evaluasi ini belum dilakukan. ${ }^{16}$

Sehingga satu sisi semua kelompok aktor kongruen dalam memahami motivasi di balik pengadaan sistem informasi ini, namun di sisi lain perbedaan muncul dalam pandangan mengenai strategi yang harus dilakukan dalam implementasi sistem infomasi ini. Pada kondisi tersebut antara kelompok manajemen dan kelompok user operator dan teknisi berada pada posisi inkongruen. Inkongruen dalam hal ini ditunjukan dengan adanya perbedaan dalam ekspektasi dan asumsi dalam strategi yang harus dilakukan mulai dari perencanaan, pemantauan proses dan evaluasi dalam implementasi sistem informasi ini.

\section{Gambaran Kelompok Profesional di Perpustakaan Mengenai Nilai-nilai yang Diharapkan Dari Implementasi Sistem Informasi di Perpustakaan UNEJ}

Kelompok manajemen mengharapkan implementasi sistem informasi ini bisa memenuhi harapan manajemen dalam hal strategis antara lain:

1. Harapannya bisa mencapai efektifitas, efisiensi, terus kompetisi dan keluasanakses

2. Meningkatkan citra. Kalau perpustakaan bagus, citra Universitas juga bagus.

3. Universitas tujuannya menjadi universitas berstandar internasional. Berarti perpustakaan nya harus berstandar internasional.

4. Untuk lembaganya berharap bisa meningkatkan kualitas pendidikan,

5. Memudahkan manajemen perpustakaan

6. Memudahkan pemustaka sehingga bisa mencari dengan mudah. Dan staff juga ada kebanggaan tersendiri.

7. Ada komunikasi yang bagus.

8. Juga tidak sering trouble.

Sementara kelompok manajemen mengarahkan nilai-nilai yang menjadi ekspektasinya dari implementasi sistem informasi ini pada nilai-nilai strategis organisasi, kelompok user operator mengarahkan ekspektasinya pada 
solusi dari permasalahan yang sering dijumpainya selama berinteraksi dengan sistem informasi ini, antara lain:

1. Jangkauan layanannya lebih baik dan luas,

2. Maksimalnya penggunaan fasilitas-fasilitas di Sistem Informasi Symphony,

3. Layanan yang lebih variatif,

4. Komunikasi yang baik dengan vendor,

5. Pekerjaan lebih cepat.

Berbeda dengan kelompok user operator, keloompok teknisi memiliki kesamaan dalam nilai yang diharapkannya dengan kelompok manajemen. Seperti diungkapkan Taufik:

Harapannya (dengan adanya Teknologi

Sistem Informasi ini) bisa menudukung Universitas. Meskipun kita paling ujung Timur. Kita kan paling modern.... ${ }^{17}$

Namun di sisi lain Taufik Hermansyah ${ }^{18}$ memiliki pandangan mengenai realitas yang ada saat ini:

... kadang saya pesimis sistem ini bisa mendukung secara maksimal pihak manajemen.Karena belum memiliki partner yang bisa berbagi permasalahan TI dan bisa memecahkan masalah.

Keberagaman dalam nilai-nilai yang diharapkan ini sesuai dengan yang disampaikan Beath \& Orlikowski, 1994; Newman \& Robey, 1992:

Each group's technological frame may differ from those of other groups. For example, developers and users of information systems typically construct different frames of meaning because their interactions with a particular application differ and they come from different social positions, educational backgrounds, historical circumstances, and interests

\section{Gambaran Kelompok Profesional di Perpustakaan Mengenai Penggunaan Teknologi (Technology In Use) Sistem Infromasi Di Perpustakaan UNEJ}

Hasil penelitian menunjukan hampir semua kelompok user operator dan teknisi menemukan kendala di lapangan terutama teknisi dan kelompok user operator di bagian sirkulasi.

\footnotetext{
${ }^{17}$ Taufik Hermansyah, wawancara 21 Januari 2014

${ }^{18}$ Wawancara 10 September 2013
}

Diantara kendala yang dihadapi kelompok user operator antara lain:

1. Di sistem ini untuk jumlah peminjam saja tidak bisa ditelusur, karena yang bisa adalah all item yang terpinjam. Hal ini terjadi mungkin karena perbedaan asumsi dengan pembuat program.

2. Dalam sistem ini banyak kemudahan namun konsultan tidak menyampaikannya, sehingga banyak fasilitas tidak digunakan maksimal

3. Banyak menu-menu yang belum dioptimalkan

4. Belum dimaksimalkannya aplikasi-aplikasi lain dalam symphony disebabkan pandangan sebagian user operator yang meragukan kemampuan konsultan, sehingga tidak termotivasi untuk mempelajari dan lebih fokus pada kegiatan rutin

5. Bila dibandingkan dengan sistem sebelumnya, mereka beranggapan sekarang paling banyak masalahnya dibanding sistem sebelumnya

Sementara kendala yang dihadapi teknisi antara lain:

1. Tidak adanya partner untuk menangani sistem informasi yang semakin kompleks

2. Bertambahnya pekerjaan dengan berbagai aplikasi yang ada pada sistem inforrmasi smphony dan sistem lainnya yang disertakan dalam pengembangan teknologi informasi saat ini antara lain RFID.

3. Ketika ada permasalahan saat ini langsung ditangani konsultan, namun hal ini di sisi lain semakin membuat teknisi tidak memahami sistem ini, dan merasa dibatasi.

Setelah berinteraksi dengan sistem informasi ini, dan memahami kondisi aktual penggunaan sistem informasi ini, kelompok user operator dan teknisi memiliki banyak asumsi, pengetahuan dan ekspektasi pada sistem informasi ini. Hal ini sejalan dengan yang dikemukakan Orlikowski dan Baroudi (1991, dalam Sahay \& Robey, 1996) :

actors are assumed to endow technology with social meanings as they engage in processes to propose, design, develop, implement, and use the technology. These meanings can shape the implementation process and subsequent use of the technology independent of technology's material properties

Dari realitas penggunaan sistem informasi ini muncul banyak ekspektasi antara lain: Usulan penambahan SDM; adanya upaya untuk 
mengadakan pelatihan; adanya proses evaluasi, dsb. Diantara ekspektasi informan pada pelatihan, mereka mengusulkan antara lain:

1. Pelatihan itu harus berkesinambungan, terutama bagian teknisi.

2. Pelatihan itu harus sesuai dengan job nya masing-masing.

3. Pelatihan itu minimal di sirkulasi apa saja. Sehingga bisa mengantisipasi dan tidak menunggu kejadian baru dipikirkan kemudian.

4. Formatnya bisa pendampingan, atau pelatihan secara umum.

Usulan untuk mengadakan pelatihan sangat krusial, Teknisi mencatat beberapa alasan pentingnya pelatihan ini antara lain:

1.Pelatihan sangat penting, karena sistem ini bukan saya yang buat dan bukan program lokal jadi perlu sharing ilmu mengenai apa kelebihan dari sistem ini.

2. Pelatihandari vendor, belumsamasekaliadahasilnya, pesertapelatihanmerasapelatihan belum berfungsi

3. Tim yang dulu dibentuk untuk sama-sama mempelajari sistem belum jalan sama sekali

4. Pelatihan dari vendor belum maksimal. Baru pada cara penggunaan. Belum pada trouble shouting.

Kesadaran akan pentingnya pelatihan ini sesuai dengan yang dikemukakan Orlikowski \&r Gash (1994) bahwa satu aspek penting dalam menggunakan suatu teknologi adalah memiliki pengetahuan yang cukup tentang teknologi tersebut. Pengetahuan tersebut diantaranya bisa didapatkan dengan mengadakan pelatihan atau pendidikan.

Sejalan dengan itu, berdasar perspektif sosial kognitif, ketika anggota suatu komunitas memiliki interpretasi individu, mereka juga biasanya memiiki satu set inti keyakinan (Porac et al 1989 dalam Orlikowski \& Gash,1994). Berkaitan dengan itu, pelatihan profesional dan pekerjaan bisa menjadi bagian usaha dari angotaanggota komunitas untuk menanamkan kegunaan suatu skema kognitif kepada yang lainnya, terutama kepada anggota baru dari kelompok tersebut.

Dari hasil penelitian ini, berikut ini tabel sebagian gambaran kongruen dan ingkongruen diantara aktor yang terlibat dalam implementasi sistem informasi. 
Tabel 1 Pernyataaan Kongruen dan In kongruen Aktor

Berdasar Konsep Technological Frame Theory

\begin{tabular}{|c|c|c|}
\hline \multirow{2}{*}{ Domain } & \multicolumn{2}{|c|}{ Pernyataan Aktor } \\
\hline & Kongruen & Inkongruen \\
\hline $\begin{array}{l}\text { Nature Of } \\
\text { Technology } \\
\text { Pandangan } \\
\text { aktor mengenai } \\
\text { Imej terhadap } \\
\text { teknologi } \\
\text { sistem } \\
\text { informasi } \\
\text { Symphony. }\end{array}$ & $\begin{array}{l}\text { "Kalau dari teknologinya menurut saya sudah } \\
\text { perfect ya. Dalam artian selalu terus } \\
\text { dikembangkan sesuai masukan dari user" } \\
\text { ".....program ini sangat lengkap software ini } \\
\text { sangat mendukung. Salah satunya ada google } \\
\text { view, smart port, dsb. Ketiga, software } \\
\text { produk Sirsidynixitu paling } \\
\text { banyakdigunakan di dunia...” (Mahfut } \\
\text { Aslam) }\end{array}$ & $\begin{array}{l}\text { "Kalau dari tampilan Sama aja. } \\
\text { Nggak begitu banyak perbedaan. } \\
\text { Yang signifikan nggak ada" (Maya) } \\
\text { “..sama aja kaya unicorn kemarin ya? } \\
\text { Kebetulan ya apa ya..ga ada } \\
\text { kesulitan...tetep aja.” (sofiah) } \\
\text { "Kalau dibanding dengan sistem } \\
\text { sebelumnya kan sama saja, } \\
\text { masalahnya kan kita belum tau yang } \\
\text { tambahannya..” (sukesi) } \\
\text { "Kalau perbedaan dengan } \\
\text { sebelumnya yah nggak begitu } \\
\text { signifikan" (Khusnun) } \\
\text { Ketika ditanya apa saja yang berubah } \\
\text { dengan teknoligi informasi saat ini di } \\
\text { perpustakaan, user pemustaka } \\
\text { berpendapat: } \\
\text { Nggak ada ya... (Merry) } \\
\text { Nggak ada sama saja kayanya (Indri) } \\
\text { Belum tau..(Wahyu) } \\
\text { Nggak ada sama saja kayanaya. } \\
\text { (Ferry) }\end{array}$ \\
\hline $\begin{array}{l}\text { Nature Of } \\
\text { Technology } \\
\text { Pandangan } \\
\text { aktor mengenai } \\
\text { kemampuan } \\
\text { teknologi } \\
\text { sistem } \\
\text { informasi } \\
\text { Symphony. }\end{array}$ & $\begin{array}{l}\text { Dari segi kemampuan sistem ini bisa } \\
\text { beradaptasi dengan perkembangan di } \\
\text { perpustakaan. Misal sekarang dengan } \\
\text { menjamurnya tablet (kurnadi) } \\
\text { Program ini sudah berstandar internasional } \\
\text { dan } \\
\text { dipersiapkanuntukantisipasijangkapanjang } \\
\text { Program ini sangatlengkap, } \\
\text { softwareinisangatmendukung. .... Selain itu } \\
\text { software produkSirsidynixitu } \\
\text { palingbanyakdigunakan di dunia (Mahfut) }\end{array}$ & $\begin{array}{l}\text { Menurut saya dari sistem sekarang } \\
\text { ini banyak kekurangannya. Kayanya } \\
\text { lebih baik yang lama, kan nggak ada } \\
\text { masalah.(sofiah) } \\
\text { Sebenarnya..kalau fiturnya bagus..ya } \\
\text { baik.saja. Cuman mungkin .karena } \\
\text { kita ga tau...yang harusnya ringan, } \\
\text { lancar, malah jadi masalah. Masalah } \\
\text { teknis ternyata bercabang (khusnun) } \\
\text {.. dibanding dulu, masalahnya juga } \\
\text { banyak sekarang, kadang masalah itu } \\
\text { juga bukan kesalahan sistem karena } \\
\text { musibah jaringannya atau dari } \\
\text { hardwarenya dsb. Tapi kan orang } \\
\text { bisa berpikiran..habis ganti sistem ini } \\
\text { ko malah mbulet .(khusnun) } \\
\text { Memang (sistem ini) lebih baik. Tapi }\end{array}$ \\
\hline
\end{tabular}




\begin{tabular}{|c|c|c|}
\hline \multirow{2}{*}{ Domain } & \multicolumn{2}{|c|}{ Pernyataan Aktor } \\
\hline & Kongruen & Inkongruen \\
\hline & & $\begin{array}{l}\text { kenapa ketika ada masalah rasanya ko } \\
\text { susaaah gitu ya (khusnun) } \\
\text { Ketika ditanya kemampuan teknologi } \\
\text { user pemustaka berpendapat: } \\
\text { Teknologinya belum maksimal. } \\
\text { (ferry) } \\
\text { Biasaa yaa..... (Wahyu) }\end{array}$ \\
\hline $\begin{array}{l}\text { Nature Of } \\
\text { Technology } \\
\text { Pandangan } \\
\text { aktor mengenai } \\
\text { Fungsi } \\
\text { teknologi } \\
\text { sistem } \\
\text { informasi } \\
\text { Symphony }\end{array}$ & $\begin{array}{l}\text { Fungsinya adalah untuk manajemen. Sehigga } \\
\text { ada istilah sistem informasi manajemen } \\
\text { perpustakaan (simperpust) yang berbasis IT. } \\
\text { (Mahfut) }\end{array}$ & $\begin{array}{l}\text { Kadang saya pesimis sistem ini bisa } \\
\text { mendukung secara maksimal pihak } \\
\text { manajemen.Karena belum memiliki } \\
\text { partner yang bisa berbagi } \\
\text { permasalahan TI dan bisa } \\
\text { memecahkan masalah. } \\
\text { (Taufik-Teknisi) }\end{array}$ \\
\hline $\begin{array}{l}\text { Technology } \\
\text { Strategy } \\
\text { Pandangan } \\
\text { aktor mengenai } \\
\text { Strategi } \\
\text { pengadaan } \\
\text { teknologi } \\
\text { dalam } \\
\text { implementasi } \\
\text { sistem } \\
\text { informasi } \\
\text { Symphony. }\end{array}$ & $\begin{array}{l}\text { Pertimbangan pertama karena sebelumnya } \\
\text { kita menggunakan software yang sama. Dari } \\
\text { perusahaan yang sama. Jadi terus dilakukan } \\
\text { peningkatan aplikasi yang digunakan, dari } \\
\text { Dynix, ke Unicorn Sirsidynix, kemudian ke } \\
\text { Symphony Sirsidynix. Kedua, karena } \\
\text { pertimbangan renstra Universitas yaitu Visi } \\
\text { Misi Universitas untuk menjadi Universitas } \\
\text { bersekala Internasional. Ketiga, software } \\
\text { produk Sirsidynix itu paling banyak } \\
\text { digunakan di dunia. } \\
\text { (Mahfut Aslam) }\end{array}$ & $\begin{array}{l}\text { Mungkin karena takutnya ada yang } \\
\text { lebih cangih lagi dari yang lama, } \\
\text { ternyata kan malah ada kendala. } \\
\text { (Sofiah) } \\
\text { Yah sudah kenal. Dan katanya lebih } \\
\text { baik. Mungkin yah. Memang lebih } \\
\text { baik. Tapi kenapa ketika ada masalah } \\
\text { rasanya ko susaaah gitu ya. Ada } \\
\text { sesuatu yang harus bayar lagi tah atau } \\
\text { gimana.Saya juga tidak tau MOU } \\
\text { nya bagaimana (Khusnun) } \\
\text { Kalau kita bicara strategi dari secara } \\
\text { konsep dari awal TI itu apa. } \\
\text { Bagaimana SWOT harus dibuat. Dari } \\
\text { sistem perencanaan..belum } \\
\text { dibicarakan secara mendetail. } \\
\text { Bagaimana ketika di perencanaan itu } \\
\text { dibuat suatu keputusan yang } \\
\text { dikerjakan bersama. Sehingga } \\
\text { strateginya tidak bersifat hit and run } \\
\text { (Kurnadi) } \\
\text { Perencanaan TSI sangat perlu. } \\
\text { Karena kalau tanpa perencanaan akan } \\
\text { amburadul. (Iswahyudi) }\end{array}$ \\
\hline $\begin{array}{l}\text { Technology } \\
\text { Strategy } \\
\text { Pandangan } \\
\text { aktor mengenai } \\
\text { Nilai-nilai yang }\end{array}$ & $\begin{array}{l}\text { Yang diharapkan adalah kemudahanakses, } \\
\text { efektifitas, } \\
\text { keluasanakses.Dalamwaktudekatkitaakanmem } \\
\text { perluasakseskeruangbaca.......Kalaudarilemba } \\
\text { gaharapannyasemua proses } \\
\text { bisadilakukandengacepat,tertib,efisien }\end{array}$ & $\begin{array}{l}\text { Saya dari pengembangan saya ingin } \\
\text { jangkauan layanannya lebih, tidak } \\
\text { sekedar mahasiswa pinjam setelah itu } \\
\text { selesai. Ada fasilitas-fasilitas di SI } \\
\text { yang baru ini belum dimanfaatkan }\end{array}$ \\
\hline
\end{tabular}




\begin{tabular}{|c|c|c|}
\hline \multirow{2}{*}{ Domain } & \multicolumn{2}{|c|}{ Pernyataan Aktor } \\
\hline & Kongruen & Inkongruen \\
\hline $\begin{array}{l}\text { diharapkan } \\
\text { dalam } \\
\text { implementasi } \\
\text { sistem } \\
\text { informasi } \\
\text { Symphony. }\end{array}$ & (Manajemen -Mahfut) & $\begin{array}{l}\text { secara maksimal (Kurnadi) } \\
\text { Pengennya sih pekerjaan lebih cepat } \\
\text { sih. Ternyata yah sama saja, mungkin } \\
\text { dari manusianya juga (Sofiah) } \\
\text { Permasalahan sudah } \\
\text { dikomunikasikan ke vendor, kadang } \\
\text { saya pesimis sistem ini bisa } \\
\text { mendukung secara maksimal pihak } \\
\text { manajemen.Karena belum memiliki } \\
\text { partner yang bisa berbagi } \\
\text { permasalahan TI dan bisa } \\
\text { memecahkan masalah (Taufik) }\end{array}$ \\
\hline $\begin{array}{l}\text { Technology In } \\
\text { Use } \\
\text { Pandangan } \\
\text { aktor mengenai } \\
\text { kondisi aktual } \\
\text { sistem } \\
\text { informasi } \\
\text { Symphony } \\
\text { dalam } \\
\text { implementasi } \\
\text { sistem } \\
\text { informasi }\end{array}$ & $\begin{array}{l}\text { Kalau positif ya. Dari sisi pencitraan kita } \\
\text { boleh berbangga menggunakan sistem } \\
\text { Informasi yang berstandar Internasional. } \\
\text { Namun sayang Ketika alat ini tidak } \\
\text { dimanfaatkan secara maksimal oleh } \\
\text { petugas(Kurnadi) }\end{array}$ & $\begin{array}{l}\text { Terus terang dari empat sistem ini } \\
\text { saya belum bekerja maksimal" } \\
\text { (Taufik ) } \\
\text { Yang saya sedikit kecewa juga } \\
\text { kepada vendor. Hal ini tidak } \\
\text { disampaikan. Kemudahan- } \\
\text { kemudahan ini tidak disampikan } \\
\text { kepada perpustakaan UNEJ. Saya } \\
\text { yakin kalau semua fasilitas ini } \\
\text { maksimal, maka akan berdampak } \\
\text { ketika kita menyatakan bahwa sistem } \\
\text { kita lebih baik dari sistem yang lama. } \\
\text { Dan tanpa adanya perbedaan layanan, } \\
\text { yang dulu dengan sekarang, mungkin } \\
\text { baik pemustaka maupun petugas akan } \\
\text { merasa sama-sama aja, karena } \\
\text { memang si petugas sendiri nggak tau, } \\
\text { atau tidak dikasih tau. Atau memang } \\
\text { masih terkendala dengan teknisnya. } \\
\text { Kenapa Menu sudah ada tapi kok } \\
\text { belum bisa (Kurnadi) } \\
\text { Hambatan yang saya rasakan adalah } \\
\text { ada beberapa menu yang belum } \\
\text { dimanfaatkan itu menurut saya } \\
\text { hambatan. Ketika kita ingin } \\
\text { melakukan variasi layanan di luar } \\
\text { yang telah ada. Tapi ketika kita punya } \\
\text { alatnnya tapi nggak bisa. Itu } \\
\text { merupakan kendala. (Kurnadi) } \\
\text { Datanya ini sekarang bermasalah. } \\
\text { Data dari } 17 \text { Des ini } \\
\text { Di dalam perjaalanan ini, TI yah tidak } \\
\text { semulus yang diharapkan, mulai } \\
\text { kendala jaringan seperti ini, sering } \\
\text { macet...(Sofiah) }\end{array}$ \\
\hline Technology In & Saya berharap banyak artinya optimislah & .....Saya mengharapkan memiliki \\
\hline
\end{tabular}




\begin{tabular}{|c|c|c|}
\hline \multirow{2}{*}{ Domain } & \multicolumn{2}{|c|}{ Pernyataan Aktor } \\
\hline & Kongruen & Inkongruen \\
\hline $\begin{array}{l}\text { Use } \\
\text { Pandangan } \\
\text { aktor mengenai } \\
\text { upaya } \\
\text { memahami } \\
\text { sistem } \\
\text { informasi } \\
\text { Symphony } \\
\text { dalam } \\
\text { implementasi } \\
\text { sistem } \\
\text { informasi }\end{array}$ & $\begin{array}{l}\text { dengan SI sepanjang proses proses } \\
\text { pembelajaran, pengenalan, kenapa SI kita } \\
\text { terapkan ini tersampaikan secara baik ke } \\
\text { temen-temen..(Kurnadi) } \\
\text { Sebetulnya semua staf itu perlu pelatihan. } \\
\text { Idealnya Mas Taufik bisa menyampaikan apa } \\
\text { yang diketahuinya bisa disampaikan secara } \\
\text { berkala. meskipun hanya dalam bentuk } \\
\text { diskusi, misal apa sih banyak yang tidak } \\
\text { dimengerti, kalau itu bisa diprogramkan, } \\
\text { diskusi, sharing informasi, tetang kedala- } \\
\text { kendala yang ditemui, bagaimana } \\
\text { mengatasinya, itu kalau dilakukan secara } \\
\text { rutin, ada yang memfasilitasi, sebab kalau } \\
\text { tidak, nggak ada ide dari bawahan yang } \\
\text { muncul, dari atas juga idenya nggak muncul. } \\
\text { (Mahfut Aslam) } \\
\text { Memang secara peribadi saya menginginkan } \\
\text { pelatihan bisa rutin, kedua saya } \\
\text { mengnginkan teman-teman mencatat } \\
\text { kejanggalan-kejanggalan yang terjadi di } \\
\text { masing-masing unit. Atau kalau perlu kita } \\
\text { ikut ke forum mail list. Pelatihan itu belum } \\
\text { sempat saja. Di sini masalahnya kan } \\
\text { kompleks... (Teknisi) }\end{array}$ & $\begin{array}{l}\text { partner yang bisa bekerjasama. } \\
\text { Apalagi dengan berbagai sistem yang } \\
\text { ada. Apalagi belum tau banyak } \\
\text { tentang sistem baru ini. Masalahnya } \\
\text { memang kompleks } \\
\text { Dulu saya minta untuk diajari } \\
\text { supaya bisa jadi superuser. Tapi } \\
\text { sekarang malah dibatasi. Padahal } \\
\text { saya menginginkan bisa mempelajari } \\
\text { sistem ini. Mereka mulai menghandel } \\
\text { seperti ini mungkin karena melihat } \\
\text { kita tidak pernah update. Lha mau } \\
\text { gimana kalau caranya kita tidak } \\
\text { dikasih tau (Taufik) } \\
\text {... Mungkin karena pelatihan dulu } \\
\text { nggak berfungsi akhirnya kita juga } \\
\text { merasa nggak bisa. Akhirnya imej di } \\
\text { kita kayanya nggak bisa pokoknya. } \\
\text { akhirnya untuk belajar lebih lanjut itu } \\
\text { belum lagi. Saya sampai sekarang } \\
\text { belum bisa pakai fasilitas untuk } \\
\text { admin yang baru. Padahal sistemnya } \\
\text { bagus. (Sukesi) }\end{array}$ \\
\hline $\begin{array}{l}\text { Pandangan } \\
\text { aktor mengenai } \\
\text { Imej terhadap } \\
\text { teknologi } \\
\text { sistem } \\
\text { informasi } \\
\text { Symphony. }\end{array}$ & $\begin{array}{l}\text { "Kalau dari teknologinya menurut saya } \\
\text { sudah perfect ya. Dalam artian selalu terus } \\
\text { dikembangkan sesuai masukan dari user" } \\
\text { ".....program ini sangat lengkap software ini } \\
\text { sangat mendukung. Salah satunya ada google } \\
\text { view, smart port, dsb. Ketiga, software } \\
\text { produk Sirsidynixitu paling } \\
\text { banyakdigunakan di dunia..." (Mahfut } \\
\text { Aslam) }\end{array}$ & $\begin{array}{l}\text { “..sama aja kaya unicorn kemarin ya? } \\
\text { Kebetulan ya apa ya..ga ada } \\
\text { kesulitan...tetep aja." (sofiah) } \\
\\
\text { ”Kalau dibanding dengan sistem } \\
\text { sebelumnya kan sama saja, } \\
\text { masalahnya kan kita belum tau yang }\end{array}$ \\
\hline
\end{tabular}




\begin{tabular}{|c|c|c|}
\hline \multirow{2}{*}{ Domain } & \multicolumn{2}{|c|}{ Pernyataan Aktor } \\
\hline & Kongruen & Inkongruen \\
\hline & & $\begin{array}{l}\text { tambahannya..” (sukesi) } \\
\text { "Kalau perbedaan dengan } \\
\text { sebelumnya yah nggak begitu } \\
\text { signifikan” (Khusnun) } \\
\text { Ketika ditanya apa saja yang berubah } \\
\text { dengan teknoligi informasi saat ini di } \\
\text { perpustakaan, user pemustaka } \\
\text { berpendapat: } \\
\text { Nggak ada ya... (Merry) } \\
\text { Nggak ada sama saja kayanya (Indri) } \\
\text { Belum tau..(Wahyu) } \\
\text { Nggak ada sama saja kayanaya. } \\
\text { (Ferry) }\end{array}$ \\
\hline $\begin{array}{l}\text { Nature Of } \\
\text { Technology } \\
\text { Pandangan } \\
\text { aktor mengenai } \\
\text { kemampuan } \\
\text { teknologi } \\
\text { sistem } \\
\text { informasi } \\
\text { Symphony. }\end{array}$ & $\begin{array}{l}\text { Dari segi kemampuan sistem ini bisa } \\
\text { beradaptasi dengan perkembangan di } \\
\text { perpustakaan. Misal sekarang dengan } \\
\text { menjamurnya tablet (kurnadi) } \\
\text { Program ini sudah berstandar internasional } \\
\text { dan dipersiapkan untuk antisipasi jangka } \\
\text { panjang Program ini sangat lengkap, } \\
\text { software ini sangat mendukung. .... Selain itu } \\
\text { software produk Sirsidynix itu paling banyak } \\
\text { digunakan di dunia (Mahfut) }\end{array}$ & $\begin{array}{l}\text { Menurut saya dari sistem sekarang ini } \\
\text { banyak kekurangannya. Kayanya } \\
\text { lebih baik yang lama, kan nggak ada } \\
\text { masalah.(sofiah) } \\
\text { Sebenarnya..kalau fiturnya bagus..ya } \\
\text { baik.saja. Cuman mungkin .karena } \\
\text { kita ga tau...yang harusnya ringan, } \\
\text { lancar, malah jadi masalah. Masalah } \\
\text { teknis ternyata bercabang (khusnun) } \\
\text { dibanding dulu, masalahnya juga } \\
\text { banyak sekarang, kadang masalah itu } \\
\text { juga bukan kesalahan sistem karena } \\
\text { musibah jaringannya atau dari } \\
\text { hardwarenya dsb. Tapi kan orang } \\
\text { bisa berpikiran..habis ganti sistem ini } \\
\text { ko malah mbulet.(khusnun) } \\
\text { Memang (sistem ini) lebih baik. Tapi } \\
\text { kenapa ketika ada masalah rasanya ko } \\
\text { susaaah gitu ya (khusnun) } \\
\text { Ketika ditanya kemampuan teknologi } \\
\text { user pemustaka berpendapat: } \\
\text { Teknologinya belum maksimal. } \\
\text { (ferry) } \\
\text { Biasaa yaa..... (Wahyu) }\end{array}$ \\
\hline $\begin{array}{l}\text { Nature Of } \\
\text { Technology } \\
\text { Pandangan }\end{array}$ & $\begin{array}{l}\text { Fungsinya adalah untuk manajemen. Sehigga } \\
\text { ada istilah sistem informasi manajemen } \\
\text { perpustakaan (simperpust) yang berbasis IT. } \\
\text { (Mahfut) }\end{array}$ & $\begin{array}{l}\text { Kadang saya pesimis sistem ini bisa } \\
\text { mendukung secara maksimal pihak } \\
\text { manajemen.Karena belum memiliki } \\
\text { partner yang bisa berbagi }\end{array}$ \\
\hline
\end{tabular}




\begin{tabular}{|c|c|c|}
\hline \multirow{2}{*}{ Domain } & \multicolumn{2}{|c|}{ Pernyataan Aktor } \\
\hline & Kongruen & Inkongruen \\
\hline $\begin{array}{l}\text { aktor mengenai } \\
\text { Fungsi } \\
\text { teknologi } \\
\text { sistem } \\
\text { informasi } \\
\text { Symphony }\end{array}$ & & $\begin{array}{l}\text { permasalahan TI dan bisa } \\
\text { memecahkan masalah. } \\
\text { (Taufik-Teknisi) }\end{array}$ \\
\hline $\begin{array}{l}\text { Technology } \\
\text { Strategy } \\
\text { Pandangan } \\
\text { aktor mengenai } \\
\text { Strategi } \\
\text { pengadaan } \\
\text { teknologi } \\
\text { dalam } \\
\text { implementasi } \\
\text { sistem } \\
\text { informasi } \\
\text { Symphony. }\end{array}$ & $\begin{array}{l}\text { Pertimbanganpertamakarenasebelumnyakita } \\
\text { menggunakansoftware yangsama. Dari } \\
\text { perusahaan yang } \\
\text { sama.Jaditerusdilakukanpeningkatanaplikasi } \\
\text { yang digunakan, dariDynix, keUnicorn } \\
\text { Sirsidynix, kemudiankeSymphonySirsidynix. } \\
\text { Kedua, karenapertimbanganrenstra } \\
\text { Universitas } \\
\text { yaituVisiMisiUniversitasuntukmenjadiUniver } \\
\text { sitasbersekala Internasional.Ketiga, software } \\
\text { produkSirsidynixitu paling banyakdigunakan } \\
\text { di dunia. } \\
\text { (Mahfut Aslam) }\end{array}$ & $\begin{array}{l}\text { Yah sudah kenal. Dan katanya lebih } \\
\text { baik. Mungkin yah. Memang lebih } \\
\text { baik. Tapi kenapa ketika ada masalah } \\
\text { rasanya ko susaaah gitu ya. Ada } \\
\text { sesuatu yang harus bayar lagi tah atau } \\
\text { gimana.Saya juga tidak tau MOU } \\
\text { nya bagaimana (Khusnun) } \\
\text { Kalau kita bicara strategi dari secara } \\
\text { konsep dari awal TI itu apa. } \\
\text { Bagaimana SWOT harus dibuat. Dari } \\
\text { sistem perencanaan..belum } \\
\text { dibicarakan secara mendetail. } \\
\text { Bagaimana ketika di perencanaan itu } \\
\text { dibuat suatu keputusan yang } \\
\text { dikerjakan bersama. Sehingga } \\
\text { strateginya tidak bersifat hit and run } \\
\text { (Kurnadi) } \\
\text { Perencanaan TSI sangat perlu. Karena } \\
\text { kalau tanpa perencanaan akan } \\
\text { amburadul. (Iswahyudi) }\end{array}$ \\
\hline $\begin{array}{l}\text { Pandangan } \\
\text { aktor mengenai } \\
\text { Nilai-nilai yang } \\
\text { diharapkan } \\
\text { dalam } \\
\text { implementasi } \\
\text { sistem } \\
\text { informasi } \\
\text { Symphony. }\end{array}$ & $\begin{array}{l}\text { Yang diharapkan adalah kemudahanakses, } \\
\text { efektifitas, } \\
\text { keluasanakses.Dalamwaktudekatkitaakanmem } \\
\text { perluasakseskeruangbaca.......Kalaudarilemba } \\
\text { gaharapannyasemua proses } \\
\text { bisadilakukandengacepat,tertib,efisien } \\
\text { (Manajemen -Mahfut) }\end{array}$ & $\begin{array}{l}\text { Saya dari pengembangan saya ingin } \\
\text { jangkauan layanannya lebih, tidak } \\
\text { sekedar mahasiswa pinjam setelah } \\
\text { itu selesai. Ada fasilitas-fasilitas di SI } \\
\text { yang baru ini belum dimanfaatkan } \\
\text { secara maksimal (Kurnadi) } \\
\text { Pengennya sih pekerjaan lebih cepat } \\
\text { sih. Ternyata yah sama saja, mungkin } \\
\text { dari manusianya juga (Sofiah) } \\
\text { Permasalahan sudah dikomunikasikan } \\
\text { ke vendor, kadang saya pesimis } \\
\text { sistem ini bisa mendukung secara } \\
\text { maksimal pihak manajemen.Karena } \\
\text { belum memiliki partner yang bisa } \\
\text { berbagi permasalahan TI dan bisa } \\
\text { memecahkan masalah (Taufik) }\end{array}$ \\
\hline
\end{tabular}




\begin{tabular}{|c|c|c|}
\hline \multirow{2}{*}{ Domain } & \multicolumn{2}{|c|}{ Pernyataan Aktor } \\
\hline & Kongruen & Inkongruen \\
\hline $\begin{array}{l}\text { Technology In } \\
\text { Use } \\
\text { Pandangan } \\
\text { aktor mengenai } \\
\text { kondisi aktual } \\
\text { sistem } \\
\text { informasi } \\
\text { Symphony } \\
\text { dalam } \\
\text { implementasi } \\
\text { sistem } \\
\text { informasi }\end{array}$ & $\begin{array}{l}\text { Kalau positif ya. Dari sisi pencitraan kita } \\
\text { boleh berbangga menggunakan sistem } \\
\text { Informasi yang berstandar Internasional. } \\
\text { Namun sayang Ketika alat ini tidak } \\
\text { dimanfaatkan secara maksimal oleh } \\
\text { petugas(Kurnadi) }\end{array}$ & $\begin{array}{l}\text { Terus terang dari empat sistem ini } \\
\text { saya belum bekerja maksimal" } \\
\text { (Taufik ) } \\
\text { Yang saya sedikit kecewa juga } \\
\text { kepada vendor. Hal ini tidak } \\
\text { disampaikan. Kemudahan- } \\
\text { kemudahan ini tidak disampikan } \\
\text { kepada perpustakaan UNEJ. Saya } \\
\text { yakin kalau semua fasilitas ini } \\
\text { maksimal, maka akan berdampak } \\
\text { ketika kita menyatakan bahwa sistem } \\
\text { kita lebih baik dari sistem yang lama. } \\
\text { Dan tanpa adanya perbedaan layanan, } \\
\text { yang dulu dengan sekarang, mungkin } \\
\text { baik pemustaka maupun petugas akan } \\
\text { merasa sama-sama aja, karena } \\
\text { memang si petugas sendiri nggak tau, } \\
\text { atau tidak dikasih tau. Atau memang } \\
\text { masih terkendala dengan teknisnya. } \\
\text { Kenapa Menu sudah ada tapi kok } \\
\text { belum bisa (Kurnadi) } \\
\text { Hambatan yang saya rasakan adalah } \\
\text { ada beberapa menu yang belum } \\
\text { dimanfaatkan itu menurut saya } \\
\text { hambatan. Ketika kita ingin } \\
\text { melakukan variasi layanan di luar } \\
\text { yang telah ada. Tapi ketika kita punya } \\
\text { alatnnya tapi nggak bisa. Itu } \\
\text { merupakan kendala. (Kurnadi) } \\
\text { Datanya ini sekarang bermasalah. } \\
\text { Data dari } 17 \text { Des ini } \\
\text { Di dalam perjaalanan ini, TI yah tidak } \\
\text { semulus yang diharapkan, mulai } \\
\text { kendala jaringan seperti ini, sering } \\
\text { macet...(Sofiah) }\end{array}$ \\
\hline $\begin{array}{l}\text { Pandangan } \\
\text { aktor mengenai } \\
\text { upaya } \\
\text { memahami } \\
\text { sistem } \\
\text { informasi } \\
\text { Symphony } \\
\text { dalam } \\
\text { implementasi } \\
\text { sistem }\end{array}$ & $\begin{array}{l}\text { Saya berharap banyak artinya optimislah } \\
\text { dengan SI sepanjang proses proses } \\
\text { pembelajaran, pengenalan, kenapa SI kita } \\
\text { terapkan ini tersampaikan secara baik ke } \\
\text { temen-temen..(Kurnadi) } \\
\text { Sebetulnya semua staf itu perlu pelatihan. } \\
\text { Idealnya Mas Taufik bisa menyampaikan apa } \\
\text { yang diketahuinya bisa disampaikan secara } \\
\text { berkala. meskipun hanya dalam bentuk } \\
\text { diskusi, misal apa sih banyak yang tidak } \\
\text { dimengerti, kalau itu bisa diprogramkan, } \\
\text { diskusi, sharing informasi, tetang kedala- } \\
\text { kendala yang ditemui, bagaimana } \\
\text { mengatasinya, itu kalau dilakukan secara }\end{array}$ & $\begin{array}{l}\text {....Saya mengharapkan memiliki } \\
\text { partner yang bisa bekerjasama. } \\
\text { Apalagi dengan berbagai sistem yang } \\
\text { ada. Apalagi belum tau banyak } \\
\text { tentang sistem baru ini. Masalahnya } \\
\text { memang kompleks } \\
\text { Dulu saya minta untuk diajari } \\
\text { supaya bisa jadi superuser. Tapi } \\
\text { sekarang malah dibatasi. Padahal } \\
\text { saya menginginkan bisa mempelajari } \\
\text { sistem ini. Mereka mulai menghandel } \\
\text { seperti ini mungkin karena melihat } \\
\text { kita tidak pernah update. Lha mau } \\
\text { gimana kalau caranya kita tidak }\end{array}$ \\
\hline
\end{tabular}




\begin{tabular}{|c|c|c|}
\hline \multirow{2}{*}{ Domain } & \multicolumn{2}{|c|}{ Pernyataan Aktor } \\
\hline & Kongruen & Inkongruen \\
\hline informasi & $\begin{array}{l}\text { rutin, ada yang memfasilitasi, sebab kalau } \\
\text { tidak, nggak ada ide dari bawahan yang } \\
\text { muncul, dari atas juga idenya nggak muncul. } \\
\text { (Mahfut Aslam) } \\
\text { Memang secara peribadi saya menginginkan } \\
\text { pelatihan bisa rutin, kedua saya } \\
\text { mengnginkan teman-teman mencatat } \\
\text { kejanggalan-kejanggalan yang terjadi di } \\
\text { masing-masing unit. Atau kalau perlu kita } \\
\text { ikut ke forum mail list. Pelatihan itu belum } \\
\text { sempat saja. Di sini masalahnya kan } \\
\text { kompleks... (Teknisi) }\end{array}$ & $\begin{array}{l}\text { dikasih tau (Taufik) } \\
\text {... Mungkin karena pelatihan dulu } \\
\text { nggak berfungsi akhirnya kita juga } \\
\text { merasa nggak bisa. Akhirnya imej di } \\
\text { kita kayanya nggak bisa pokoknya. } \\
\text { akhirnya untuk belajar lebih lanjut itu } \\
\text { belum lagi. Saya sampai sekarang } \\
\text { belum bisa pakai fasilitas untuk } \\
\text { admin yang baru. Padahal sistemnya } \\
\text { bagus. (Sukesi) } \\
\text { kendalanya sistem ini di Indonesia } \\
\text { tidak memiliki partner. Kedua } \\
\text { kendalanya di Formis, responya } \\
\text { lama sekali. Kalau mau pake di luar } \\
\text { itu, misal dengan Australia. Saya } \\
\text { disalahkan. Jadi segala sesuatu } \\
\text { kendala kasus itu harus ke Formis. } \\
\text { Berbeda penanganannya antara } \\
\text { Australia dengan Malaysia. Kalau } \\
\text { dengan Australia kita dibimbing } \\
\text { untuk lebih paham dan bisa, kalau } \\
\text { dengan Malaysia, Cuma dikasih } \\
\text { jawaban saja (Taufik) }\end{array}$ \\
\hline
\end{tabular}




\section{SIMPULAN DAN SARAN}

\section{Simpulan}

1. Sifat dasar teknologi dalam implementasi sistem informasi di Perpustakaan UNEJ ini dinilai berbeda oleh berbagai kelompok profesional di perpustakaan walaupun pada awalnya semua kelompok profesional di perpustakaan memberi gambaran positif dalam hal imej dan kemampuan sistem informasi Symphony. Hal ini menggambarkan terdapat banyak perbedaan dalam asumsi, ekspektasi, dan pengetahuan mengenai sitem informasi Symphony diantara keompok profesional di Perpustakaan.

2. Dalam memberikan gambaran mengenai strategi yang dilaksanakan dalam implementasi teknologi sistem informasi Symphony di Perpustakaan, masing-masing kelompok profesional di perpustakaan memberikan penilaian yang berbeda, meskipun mereka memiliki kesamaan dalam memahami motivasi di balik pengadaan sistem informasi ini. Selain itu, meskipun manajemen memahami pentingnya perencanaan, namun manajemen belum membuat perencanaan dalam implementasi teknologi sistem informasi, sehingga kelompok profesional lainnya yaitu teknisi dan user operator memberikan banyak masukan mengenai strategi yang seharusnya dilakukan.

3. Kelompok Teknisi dan kelompok user operator sebagai kelompok profesional di perpustakaan yang banyak terlibat dalam penggunaan teknologi sistem informasi Symphony ini, mengemukakan banyak kendala dalam implementasi sistem infornasi Symphony, karena itu mereka memiliki kesamaan dalam memahami pentingnya upaya pembelajaran untuk memaksimalkan penggunaan teknologi sistem informasi ini melalui proses pelatihan.

\section{Saran}

1. Agar kemampuan teknologi sistem informasi Symphony yang diimplementasikan di perpustakaan bisa dimaksimalkan, penting bagi Manajemen untuk : 1) Membuat mekanisme agar sistem Informasi Symphony dengan semua aplikasi yang dimilikinya bisa dimaksimalkan diantaranya pelatihan internal, Fokus Grup Discussion (FGD),dsb; 2) Mengusulkan SDM yang kompeten di bidang teknologi informasi; 3) Membuat program sosialisasi kepada pemustaka mengenai teknologi yang diimplementasikan di perpustakaan, misal dengan menggunakan sarana promosi seperti spanduk, brosur, dsb;

2. Agar tujuan implementasi sistem informasi bisa dipahami bersama, penting bagi manajemen untuk membangun frame yang sama mengenai strategi yang dilakukan dalam implementasi sistem informasi dengan kelompok profesional di perpustakaan lainnya yakni teknisi dan user operator. Diantaranya dengan melakukan sosialisasi kebijakan strategis yang diambil, mengoptimalkan bentuk komunikasi internal yang telah ada seperti rapat rutin bulanan dengan kepala bidang, pertemuan dua bulanan dengan seluruh staf, dsb. Selain itu sangat krusial bagi manajemen untuk membuat perencanaan strategis dalam proses implementasi sistem informasi di perpustakaan.

3. Agar semua kendala dalam implementasi sistem informasi ini bisa diidentifikasi dan segera mendapatkan pemecahannya, penting bagi manajemen untuk melakukan proses evaluasi pada proses implementasi informasi di perpustakaan. Selain itu manajemen perlu mengambil kebijakan untuk membuat formula pembelajaran yang efektif untuk memaksimalkan penggunaan sistem informasi Symphony ini. Misalkan dengan membuat agenda pelatihan, serta meminta masukan semua kelompok yang terlibat mengenai bentuk pelatihan yang efektif.

\section{DAFTAR PUSTAKA}

Creswell, John W. 2012.Research Design : Pendekatan Kualitatif, Kuantitatif, dan Mixed. Yogyakarta : Pustaka Pelajar, 2012.

Daymon, Christine dan Immy Holloway. 2008.Metode-Metode Riset Kualitatif dalam Public Relation dan Marketing Communication. Yogyakarta: Bentang, 2008.

Klein, Hans K. dan Kleinman, Daniel Lee. 2002. gSyo,c \&ia lH Cuomnasntr uVcatliuoens of Technology from Science, Technology, \& 
Human Values, Vol. 27. [Online] 2002. [Dikutip: 21 August 2013.]

Sahay, Sundep dan Robey, Daniel. 1996. 1996, Accounting, Management and Information Technology, Vol. 6, No.4, hal. 255-282; volume 6, No. 4.

Putu Laxman Pendit . 2007.Perpustakaan Digital : Perspektif Perpustakaan Perguruan Tinggi Indonesia. Jakarta : Sagung Seto, 2007.

Yin, Robert K. 2013.Metode, Studi Kasus Desain dan. Jakarta : Rajawali Pers, 2013. 